\title{
Identification of regulated proteins by resveratrol in glutamate-induced cortical injury of newborn rats
}

\author{
Sang-A GIM1)\#, Dong-Ju PARK ${ }^{1) \#, ~ J u-B i n ~ K A N G 1) \#, ~ F a w a d-A l i ~ S H A H ~}{ }^{1,2)}$ and \\ Phil-Ok KOH ${ }^{1) *}$ \\ 1)Department of Anatomy, College of Veterinary Medicine, Research Institute of Life Science, \\ Gyeongsang National University, 501 Jinjudaero, Jinju, 52828, South Korea \\ ${ }^{2)}$ Current affiliation: Riphah Institute of Pharmaceutical Sciences, Riphah International University, \\ near Hajj Complex, I-14, Islamabad, Islamabad Capital Territory 46000, Pakistan
}

\section{J. Vet. Med. Sci.}

83(4): 724-733, 2021

doi: $10.1292 /$ jvms.21-0013

Received: 8 January 2021

Accepted: 15 February 2021 Advanced Epub:

12 March 2021

\begin{abstract}
Glutamate induces neuronal damage by generating oxidative stress and neurotoxicities. The neurological damage caused by glutamate is more severe during brain development in newborns than in adults. Resveratrol is naturally present in a variety of fruits and medicinal plants and exerts a neuroprotective effect against brain damage. The goal of this study was to evaluate the neuroprotective effects of resveratrol and to identify changed proteins in response to resveratrol treatment during glutamate-induced neonatal cortical damage. Sprague-Dawley rat pups (7 days old) were randomly divided into vehicle, resveratrol, glutamate, and glutamate and resveratrol groups. The animals were intraperitoneally injected with glutamate $(10 \mathrm{mg} / \mathrm{kg})$ and/or resveratrol $(20 \mathrm{mg} /$ $\mathrm{kg}$ ) and their brain tissue was collected $4 \mathrm{hr}$ after drug administration. Glutamate exposure caused severe histopathological changes, while resveratrol attenuated this damage. We identified regulated proteins by resveratrol in glutamate-induced cortical damaged tissue using two-dimensional gel electrophoresis and mass spectrometry. Among identified proteins, we focused on eukaryotic initiation factor $4 A 2$, $\gamma$-enolase, protein phosphatase $2 A$ subunit $B$, and isocitrate dehydrogenase. These proteins decreased in the glutamate-treated group, whereas the combination treatment of glutamate and resveratrol attenuated these protein reductions. These proteins are anti-oxidant proteins and anti-apoptotic proteins. These results suggest that glutamate induces brain cortical damage in newborns; resveratrol exerts a neuroprotective effect by controlling expression of various proteins with anti-oxidant and anti-apoptotic functions.
\end{abstract}

KEY WORDS: cerebral cortex, glutamate, neonate, proteomics, resveratrol

Glutamate $\left(\mathrm{C}_{5} \mathrm{H}_{9} \mathrm{NO}_{4}\right)$ is a major excitatory neurotransmitter in the central nervous system [44]. It is associated with a variety of functions including memory, learning, cognition, and behavior [42]. However, excessive glutamate exposure induces oxidative stress and pathological changes, and consequently leads to cell death in neuron [39, 51]. It accelerates intracellular calcium influx through the glutamate receptor. The increased concentration of calcium in neurons causes severe damage to mitochondria, eventually results in cell death [6]. Glutamate excitotoxicity causes nerve damage in both adults and newborns [5, 48]. Moreover, glutamate excitotoxicity in newborns delays the development of neurological reflexes and motor coordination abilities [23, 24]. Glutamate receptors play an important role in neural circuit formation and synaptic plasticity regulation in the central nervous system during brain development [4, 21].

Resveratrol is a natural polyphenolic vegetable ingredient contained in red wine, grapes, berries, and nuts. It exerts various biological effects such as anti-oxidant, anti-inflammatory, and anti-cancer properties [18, 22, 65]. Resveratrol reduces anxiety, relieves nerve loss and cognitive impairment, and exerts a neuroprotective effect against traumatic brain injury in immature rats [57]. Resveratrol has significant anti-oxidant activity and acts as a neuroprotectant against $\beta$-amyloid toxicity, excitatory toxicity, ischemia, and hypoxia [16, 25, 63, 67]. We have previously shown the neuroprotective effects of resveratrol on focal cerebral ischemia in adult rats [54]. The neuroprotective role of resveratrol in glutamate excitotoxicity has been reported in adult models [61, 68], but little is known about its effect on the newborn brain. We propose that resveratrol exerts neuroprotective effects by regulating various proteins in glutamate-exposed newborn cortices. Therefore, we investigated the histopathological changes of resveratrol in glutamate-exposed newborn cortices and identified the regulated proteins by resveratrol treatment.

*Correspondence to: Koh, P.-O.: pokoh@gnu.ac.kr

\#These authors contributed equally to this work.

(O2021 The Japanese Society of Veterinary Science

This is an open-access article distributed under the terms of the Creative Commons Attribution Non-Commercial No Derivatives (by-nc-nd) License. (CC-BY-NC-ND 4.0: https://creativecommons.org/licenses/by-nc-nd/4.0/) 


\section{MATERIALS AND METHODS}

\section{Experimental animal}

Pregnant female Sprague-Dawley rats were purchased from Samtako Co. (Animal Breeding Center, Osan, Korea), and rat pups were gotten. Animals were raised at control temperature $\left(25^{\circ} \mathrm{C}\right)$ and lighting $(12: 12 \mathrm{light} /$ dark cycle), and were supplied with standard chau (Samyang, Seoul, Korea) and water ad libitum. All the processes of the experimental animals were performed as a guideline of the Institutional Animal Care and Use Committee in Gyeongsang National University. Rat pups (11-15 g) at post-natal 7 day were randomly divided into four groups: vehicle, glutamate, resveratrol, glutamate and resveratrol treatment group ( $\mathrm{n}=7$ per group). Resveratrol (Sigma-Aldrich, St. Louis, MO, USA) was dissolved in $0.1 \%$ dimethyl sulfoxide (DMSO) with phosphate buffered saline (PBS) and glutamate was dissolved in only PBS [64]. Resveratrol $(20 \mathrm{mg} / \mathrm{kg})$ and/or glutamate $(10 \mathrm{mg} / \mathrm{kg})$ were administered to animals by intraperitoneal injection [64]. Vehicle-treated animals were administrated with only DMSO solution without drugs. Animals were sacrificed $4 \mathrm{hr}$ after treatment and cerebral cortical tissues were collected. The brain cortex was fixed to $4 \%$ paraformaldehyde solutions for morphological studies and frozen in liquid nitrogen, maintaining at $-70^{\circ} \mathrm{C}$ for protein research.

\section{Hematoxylin and eosin staining}

Fixed cerebral cortex tissues were washed with tap water, dehydrated with gradient ethyl alcohol series from $70 \%$ to $100 \%$, and cleaned with xylene. Tissues were embedded into paraffin using Embedding center (Leica, Westlar, Germany) and made into paraffin tissue blocks. Tissue blocks were sectioned $4 \mu \mathrm{m}$ thick using a rotary microtome (Leica) and sliced sections were placed on slide glass. Tissue slides were deparaffinized with xylene and hydrated with ethyl alcohol series from $100 \%$ to $70 \%$, and were kept in water. Tissue slide were stained with Harris' hematoxylin solution (Sigma-Aldrich) for $3 \mathrm{~min}$, washed with tap water for 10 min, reacted with Eosin Y (Sigma-Aldrich) for $1 \mathrm{~min}$. After staining process, tissue slides were dehydrated with gradient ethyl alcohol series, cleaned with xylene, and sealed with a permount mounting solution (Fisher scientific, Fair Lawn, NJ, USA). The morphological changes of the cerebral cortex were observed using Olympus microscopy (Olympus, Tokyo, Japan) and microscopic images were taken.

\section{Two-dimensional gel electrophoresis}

A proteomic approach was carried out as a previously described method [26]. The cerebral cortex tissues were prepared in lysis buffer ( $8 \mathrm{M}$ urea, $4 \% \mathrm{CHAPS}, 0.2 \%$ ampholyte, $40 \mathrm{mM}$ Tris-HCl) and homogenize using a tissue homogenizer. After centrifugation at $20,000 \mathrm{rpm}$ for $20 \mathrm{~min}$ at $4^{\circ} \mathrm{C}$, the supernatant was collected and proteins were precipitated with $10 \%$ trichloroacetic acid for 30 min at room temperature. The pellets were collected by centrifugation of the precipitated protein. After washing, pellets were washed with $1 \mathrm{M}$ Tris- $\mathrm{HCl}$ (pH 7.6), dried for $1 \mathrm{hr}$ and sample buffer [ $8 \mathrm{M}$ urea, 4\% CHAPS, 0.2\% ampholyte, $40 \mathrm{mM}$ Tris-HCl, $2 \mu \mathrm{g} / \mathrm{ml} \mathrm{dithiothreitol}$ (DTT)] was added to dried pellets. The sonication phase was performed for $3 \mathrm{~min}$, and the protein sample was incubated for $1 \mathrm{hr}$ at room temperature and centrifuged at $15,000 \mathrm{~g}$ for $30 \mathrm{~min}$ at $4^{\circ} \mathrm{C}$. The supernatants were collected and total protein concentrations were measured using Bradford protein assay kit (Bio-Rad, Hercules, CA, USA) according to the manufacturer's protocol. The immobilized $\mathrm{pH}$ gradient (IPG) gel strips (17 cm, $\mathrm{pH} 4-7$ and $\mathrm{pH}$ 6-9; Bio-Rad) were rehydrated with rehydration solution (8 M urea, 2\% CHAPRS, $20 \mathrm{mM}$ DTT) containing $50 \mu \mathrm{g}$ protein sample, $0.5 \%$ IPG buffer, bromophenol blue for $15 \mathrm{hr}$ at room temperature. The focus step was performed with conditions of $250 \mathrm{~V}$ for $15 \mathrm{~min}, 10,000 \mathrm{~V}$ for $3 \mathrm{hr}$, and 10,000 to 5,000 V for $3 \mathrm{hr}$ using EttanIPGphor 3 (GE Healthcare, Uppasala, Sweden). The strips were reacted with equilibration buffer [6 $\mathrm{M}$ urea, $30 \%$ glycerol, $2 \%$ sodium dodecyl sulfate (SDS), 50 mMTris- $\mathrm{HCl}$, bromophenol blue] including $1 \%$ DTT for $10 \mathrm{~min}$ and treated with equilibration buffer containing $2.5 \%$ iodoacetamide. IPG gel strips were loaded into $12 \% \mathrm{SDS}$ gel, and two-dimensional separation was performed at $10 \mathrm{~mA}$ for $10 \mathrm{hr}$ at $100^{\circ} \mathrm{C}$ using protein-II XI electrophoresis equipment (Bio-Rad). Electrophoresis was performed until bromophenol blue dye reached the underline of the gel.

\section{Silver staining and image analysis}

After electrophoresis, gel was dipped in a fixed solution (12\% acetic acid, 50\% methanol) for $2 \mathrm{hr}$. The gels were washed with $50 \%$ ethanol for $20 \mathrm{~min}$, sensitized with $0.02 \%$ sodium thiosulfate for $1 \mathrm{~min}$, and rinsed with distilled water for $3 \mathrm{~min}$. The sensitized gels were stained with silver stain solution ( $0.2 \%$ silver nitrate, $0.03 \%$ formaldehyde) for 20 min and washed with distilled water for $2 \mathrm{~min}$. The protein spots were visualized by reaction with develop solution ( $2 \%$ sodium carbonate, $0.02 \%$ formaldehyde). After stopping the reaction with the suspension solution (1\% acetic acid), stained gel was scanned using Agfar ARCUS 1200TM (Agfar-Gevaert, Mortsel, Belgium). The images were analyzed using PDQuest 2-DE analysis software (Bio-Rad) and protein spots with significant differences in expression among groups were investigated.

\section{MALDI-TOF and protein identification}

The specific protein spots were collected from stained gels and destained by reacting with destaining solution ( $30 \mathrm{mM}$ potassium hexacyanoferrate, $100 \mathrm{mM}$ sodium thiosulfate) and washing solution (10\% acetic acid in 50\% methanol). After destaining, gel spots were dehydrated with $50 \mathrm{mM}$ ammonium bicarbonate and acetonitrile, and vacuum-dried with a centrifuge for 20 min. The gel spot were incubated with reduction solution (10 $\mathrm{mM}$ DTT in $0.1 \mathrm{M}$ ammonium bicarbonate) for $45 \mathrm{~min}$ at $56^{\circ} \mathrm{C}$, and then in the alkylation solution $(55 \mathrm{mM}$ iodoacetamide in $0.1 \mathrm{M}$ ammonium bicarbonate) for $30 \mathrm{~min}$ in dark room. The gel spots were dehydrated with $0.1 \mathrm{M}$ ammonium bicarbonate and acetonitrile, and dried with vacuum centrifuge for $20 \mathrm{~min}$. Dried gel spots were incubated with digestion solution ( $12.5 \mathrm{ng} / \mathrm{ml}$ trypsin, $0.1 \%$ octyl beta-D glycopyranside in $50 \mathrm{mM}$ ammonium bicarbonate) for overnight at $37^{\circ} \mathrm{C}$. The trypsin-digested proteins were collected by extraction buffer ( $1 \%$ trifluoroacetic acid in $66 \%$ acetonitrile), and extracted proteins were dehydrated for $2 \mathrm{hr}$ by vacuum centrifugation. Nitrocellulose solution was prepared by dissolving nitrocellulose in acetone and isopropanol was added the same volume of acetone. The alpha-cyano-4- 
hydroxycinnamic acid (CHCA) solution was prepared by dissolving CHCA in acetone. The nitrocellulose solution and CHCA solution were mixed at a ratio of 1:4 and the final matrix solution was prepared by adding angiotensin and neurotensin $(2 \mu \mathrm{l} / \mathrm{ml})$. The dried proteins were dissolved in the extraction buffer and matrix solution, and the samples were mounted on the matrix-assisted laser desorption ionization time flight (MALDI-TOF) plate. After the samples were completely dried, MALDI-TOF was performed using Voyager-DE STR (Applied Biosystem, Foster City, CA, USA). The proteins were analyzed by NCBI and MS-FIT software and protein sequence information was searched from SWISS-PROT and $\mathrm{NCBI}$ sequence database.
Table 1. Sequence of the primers used for PCR amplification

\begin{tabular}{|c|c|c|}
\hline Gene & $\begin{array}{l}\text { Primer sequences } \\
\text { (F, Forward; R, Reverse) }\end{array}$ & $\begin{array}{l}\text { Product } \\
\text { (bp) }\end{array}$ \\
\hline $\begin{array}{l}\text { Eukaryotic initiation } \\
\text { factor } 4 \mathrm{~A}-2\end{array}$ & $\begin{array}{l}\text { F: 5'-CAGAGGGAATGGACCCCGAT-3' } \\
\text { R: } \quad \text { 5'-GTGGCTGTCTTGCCAGTACC-3' }\end{array}$ & 214 \\
\hline$\gamma$-enolase & $\begin{array}{ll}\text { F: } & \text { 5'- GCACTCTACCAGGACTTTG-3' } \\
\text { R: } & \text { 5'- CGATGACTCACCATAACCC-3' }\end{array}$ & 284 \\
\hline $\begin{array}{l}\text { Protein phosphatase } 2 \mathrm{~A} \\
\text { subunit } \mathrm{B}\end{array}$ & $\begin{array}{l}\text { F: } \\
\text { 5'-CCTGGTATGCCAAACTCGAT-3' } \\
\text { R: }\end{array}$ & 223 \\
\hline $\begin{array}{l}\text { Isocitrate dehydrogenase } \\
(\mathrm{NAD}+) \text { subunit alpha }\end{array}$ & $\begin{array}{l}\text { F: 5'-AAAAATCCATGGCGGTTCTGTG -3' } \\
\text { R: } \quad 5^{\prime} \text { - GGTCCCCATAGGCGTGTCG -3' }\end{array}$ & 404 \\
\hline$\beta$-actin & $\begin{array}{ll}\text { F: } & \text { 5'-GGGTCAGAAGGACTCCTACG-3' } \\
\text { R: } & 5^{\prime} \text { - TTTCACTGCGGCTGATGTAG-3' }\end{array}$ & 238 \\
\hline
\end{tabular}

\section{Western blot analysis}

The cerebral cortex was isolated from the whole brain and homogenized in lysis buffer [1\% Triton X-100 in PBS, 1 mM EDTA ( $\mathrm{pH}$ 7.4) and $200 \mu \mathrm{M}$ phenyl methyl sulfonyl fluoride]. Tissue homogenate was centrifuged at 15,000 $g$ for 20 min and supernatant was collected from each sample. Protein concentration for each sample was measured with the BCA Protein Assay Kit (Pierce). Brain tissue samples were denatured in sample buffer for $3 \mathrm{~min}$ at $100^{\circ} \mathrm{C}$ and a total of $30 \mu \mathrm{g}$ protein sample was loaded to $10 \%$ sodium dodecyl sulfate poly-acrylamide (SDS-PAGE) gels for electrophoresis. The protein was transferred to a polyvinylidene fluoride membrane (PVDF) membrane and blocked with 5\% skim milk for $1 \mathrm{hr}$. Membranes were washed with Tris-buffered saline containing $0.1 \%$ Tween-20 (TBST) and treated for overnight at $4{ }^{\circ} \mathrm{C}$ with the following primary antibodies: anti-eukaryotic initiation factor $4 \mathrm{~A} 2$ (eIF4A2), anti- $\gamma$-enolase, anti-protein phosphatase $2 \mathrm{~A}$ subunit B, anti-isocitrate dehydrogenase (ICDH), and anti- $\beta$-actin (1:1,000, Santa Cruz Biotechnology, Dallas, TX, USA). The membrane was washed with TBST and incubated with horseradish peroxidaseconjugated anti-mouse IgG or anti-rabbit IgG for $2 \mathrm{hr}$ at room temperature (1:5,000, Pierce). The membrane was once again washed with TBST and reacted with chemiluminescence detection reagent (GE Healthcare, Little Chalfont, Buckinghamshire, UK). The membrane was developed and finally the protein band was visualized on an X-ray film (Fuji Film, Tokyo, Japan).

\section{Reverse transcription-polymerase chain reaction}

The cerebral cortex was mixed with Trizol Reagent (Life Technologies, MD, Rockville, MD, USA) and homogenized using a tissue homogenizer (Qiagen, Hilden, Germany). Chloroform was added to the homogenized sample and samples were incubated for $10 \mathrm{~min}$ at $4^{\circ} \mathrm{C}$. The mixture was centrifuged at $13,000 \mathrm{~g}$ for $15 \mathrm{~min}$ at $4^{\circ} \mathrm{C}$ and the supernatant collected. Samples were added with isopropanol, incubated for $5 \mathrm{~min}$ at $4^{\circ} \mathrm{C}$, and centrifuged at $13,000 \mathrm{~g}$ for $5 \mathrm{~min}$ at $4^{\circ} \mathrm{C}$. The supernatant was discarded and the precipitated RNA pellet was washed with 70\% ethyl alcohol and air dried. The RNA pellet was then dissolved in diethyl pyrocarbonate water. The extracted total RNA sample $(1 \mu \mathrm{g})$ was reverse transcribed into complementary DNA (cDNA) with the Superscript III first strand system (Invitrogen, Carlsbad, CA, USA). Each target gene sequence of cDNA was detected by primers designed for the target gene. Primer DNA sequences are shown in Table 1. The detected gene sequence was amplified by polymerase chain reaction (PCR). PCR was performed under the following conditions: cDNA initial denaturation for 5 min at $94^{\circ} \mathrm{C}$; denaturation for $30 \mathrm{sec}$ at $94^{\circ} \mathrm{C}$, primer annealing for $30 \mathrm{sec}$ at $54^{\circ} \mathrm{C}$, and elongation for 1 min at $72^{\circ} \mathrm{C}$; final extension for 10 min at $72^{\circ} \mathrm{C}$. The replication step was repeated for 30 cycles. Amplified DNA samples were added with a Loading Star dye (Dyne Bio, Seongnam, Korea) and electrophoresed on 1\% agarose gel. The electrophoretic DNA band was detected by ultraviolet light.

\section{Statistical analysis}

All experimental data are represented as means \pm standard error of mean (S.E.M.). The data of each group were analyzed by two-way ANOVA and post-hoc Scheffe's test was conducted. The differences in comparisons were considered significant at $P<0.05$.

\section{RESULTS}

Figure 1 showed histopathological changes in cerebral cortex damage caused by glutamate exposure. In vehicle-treated animals, the cerebral cortex contained pyramidal cells with typical normal morphology and well-developed dendritic cells (Fig. 1A). Moreover, only resveratrol-treated animals had elongated dendrites and pyramidal neurons (Fig. 1B). However, glutamate-exposed animals have atypically shaped neuron with short dendrites and swollen neurons (Fig. 1C). These histopathologic changes in the glutamate-treated animals were alleviated by resveratrol treatment (Fig. 1D).

Figure 2 showed a two-dimensional electrophoretic map image of the cerebral cortex. About 830 protein spots were detected per image. We identified 28 protein spots with double intensity changes between only glutamate and glutamate and resveratrol cotreated animals. These proteins were described by MALDI-TOF analysis. Eight proteins were not identifiable and were considered unknown. Detected protein sequences ranged from 21-61\% (Table 2). Among the identified proteins, this study focused on eIF4A2, $\gamma$-enolase, protein phosphatase $2 \mathrm{~A}$ subunit B, and ICDH (Fig. 3). These proteins were associated with oxidative stress and energy 


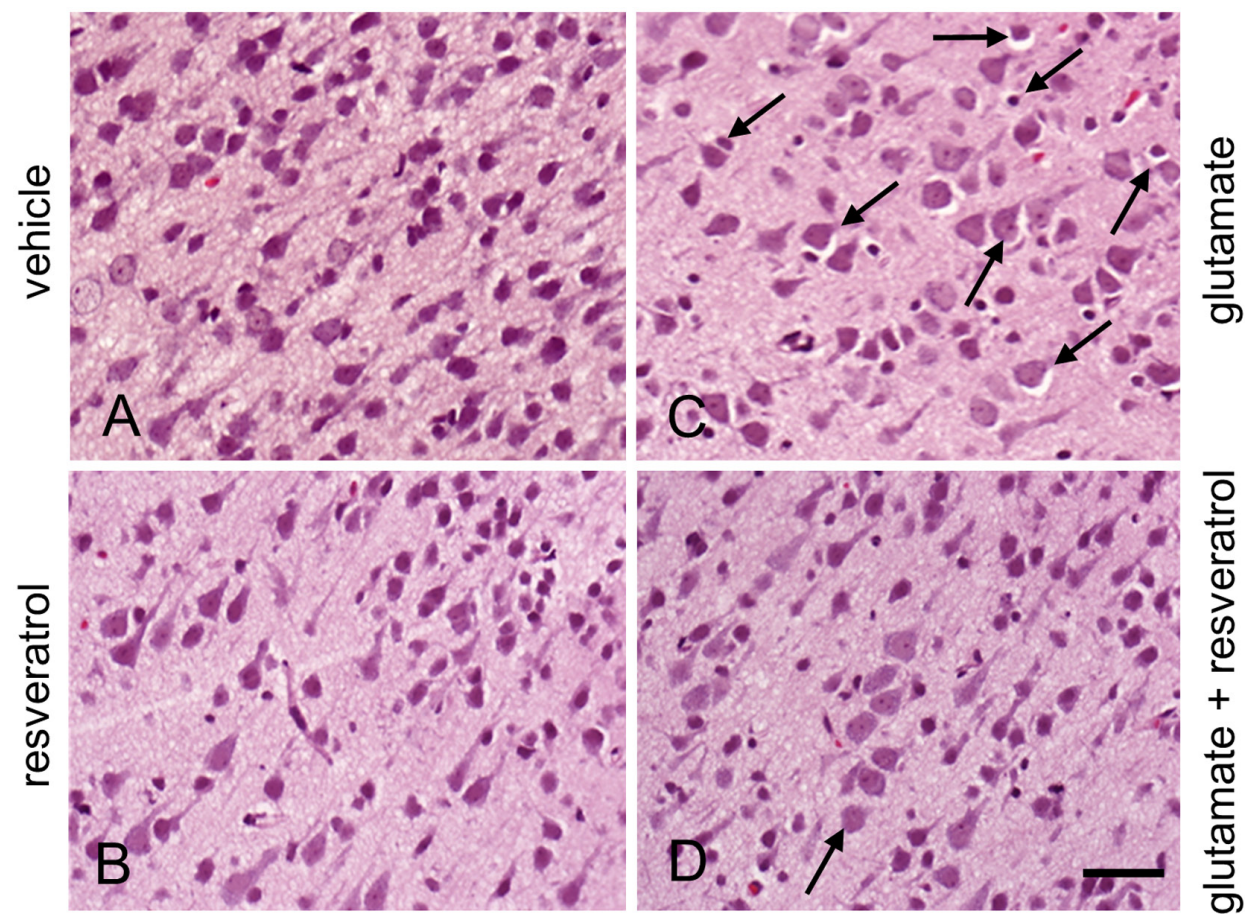

Fig. 1. Representative photomicrographs of hematoxylin and eosin staining in the neonatal cerebral cortex of vehicle- (A), resveratrol- (B), glutamate- (C), and glutamate and resveratrol co-treated animals (D). Normal pyramidal cells with well-developed dendrites were observed in the vehicle animals, while swollen neuron with atypical shapes were observed in the glutamate-treated animals. These morphological changes were alleviated in the glutamate and resveratrol co-treated animals. Arrows present damaged neuron. Scale bar $=40 \mu \mathrm{m}$
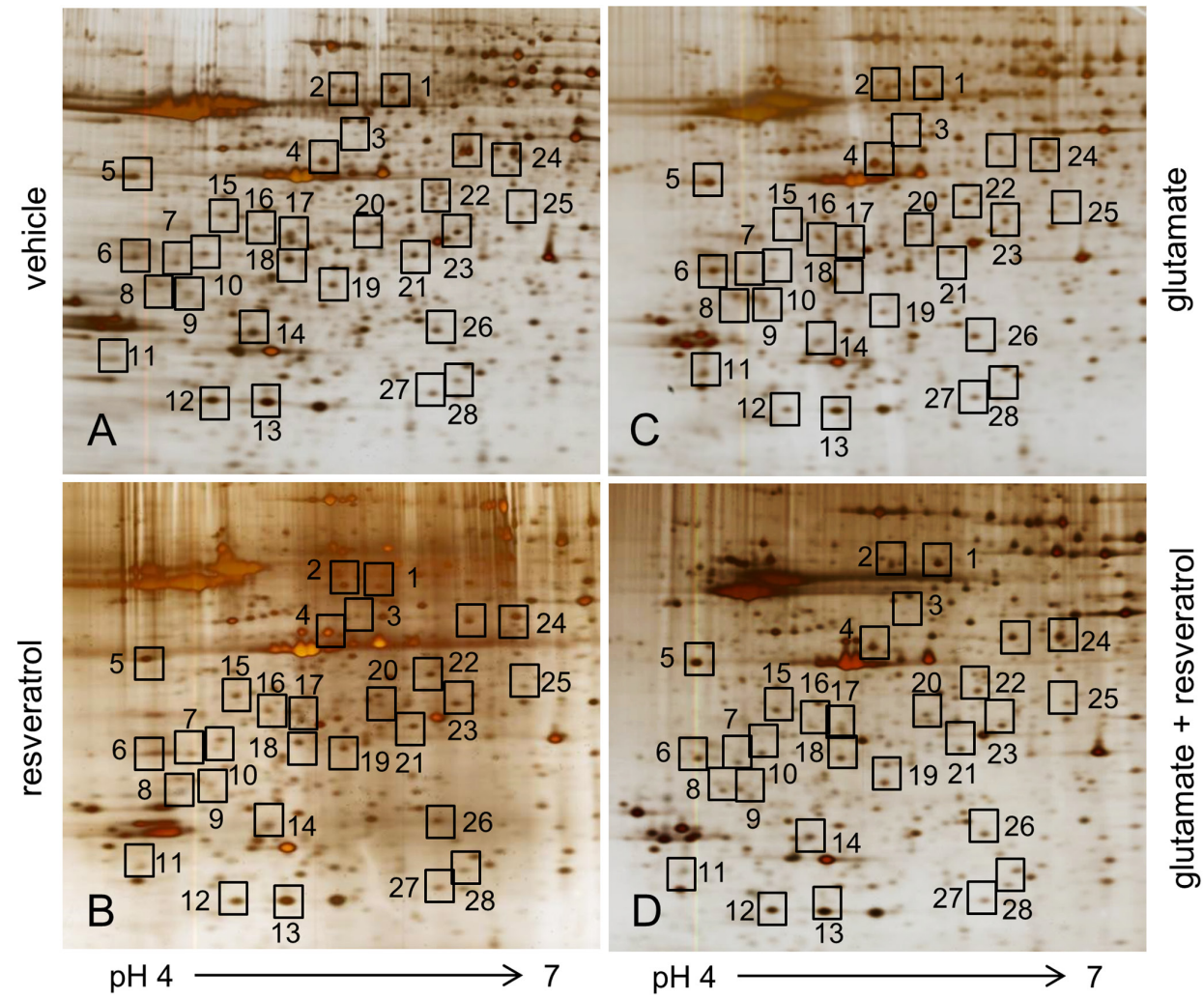

Fig. 2. Two-dimensional electrophoresis analysis of proteins in neonatal cerebral cortex of vehicle- (A), resveratrol- (B), glutamate- (C), and glutamate and resveratrol co-treated animals (D). Isoelectric focusing was performed at pH 4-7 using IPG strips, followed by second-dimensional separation on $7.5-17.5 \%$ gradient SDS gels stained with silver. The square presents the protein spot with double intensity change between the glutamate- and the co-treated animals. 
Table 2. List of proteins that were differently expressed between glutamate- and glutamate and resveratrol-treated animals

\begin{tabular}{|c|c|c|c|c|c|c|}
\hline $\begin{array}{l}\text { Spot } \\
\text { no }\end{array}$ & Protein name & $\begin{array}{l}\text { Accession } \\
\text { no }\end{array}$ & $\begin{array}{l}\text { MW } \\
(\mathrm{kDa})\end{array}$ & $\mathrm{pI}$ & $\begin{array}{c}\text { Mass } \\
\text { matched }\end{array}$ & $\begin{array}{c}\text { Sequence } \\
\text { coverage }(\%)\end{array}$ \\
\hline 1 & Dihydropyrimidinase-related protein 2 & P47942 & 62.27 & 6.00 & $24 / 103$ & 52 \\
\hline 2 & Unknown & & & & & \\
\hline 3 & Eukaryotic initiation factor 4A-2 & Q5RKI1 & 46.73 & 5.33 & $16 / 82$ & 40 \\
\hline 4 & Eukaryotic initiation factor $4 \mathrm{~A}-2$ & Q5RKI1 & 46.37 & 5.33 & $16 / 82$ & 40 \\
\hline 5 & $\gamma$-enolase & P07323 & 47.14 & 5.00 & $14 / 70$ & 34 \\
\hline 6 & Ubiquitin carboxy-terminal hydrolase L1 & Q7TQI3 & 31.27 & 4.85 & $11 / 66$ & 58 \\
\hline 7 & Unknown & & & & & \\
\hline 8 & Ubiquitin thiolesterase OTUB1 & B2RYG6 & 31.27 & 4.80 & $14 / 39$ & 61 \\
\hline 9 & Thioredoxin & Q920J4 & 32.23 & 4.84 & $8 / 87$ & 42 \\
\hline 10 & Thioredoxin & Q920J4 & 32.23 & 4.84 & $8 / 87$ & 42 \\
\hline 11 & Unknown & & & & & \\
\hline 12 & Peroxiredoxin 2 & Q61171 & 21.64 & 5.30 & $9 / 51$ & 46 \\
\hline 13 & Unknown & & & & & \\
\hline 14 & Unknown & & & & & \\
\hline 15 & Unknown & & & & & \\
\hline 16 & Mu-crystallin & Q9QYU4 & 33.33 & 5.34 & $9 / 86$ & 24 \\
\hline 17 & Mu-crystallin & Q9QYU4 & 33.55 & 5.30 & $6 / 114$ & 21 \\
\hline 18 & Protein phosphatase $2 \mathrm{~A}$, subunit $\mathrm{A}$ & P63331 & 35.60 & 5.30 & $13 / 110$ & 45 \\
\hline 19 & Unknown & & & & & \\
\hline 20 & Mu-crystallin & Q9QYU4 & 33.55 & 5.30 & $11 / 88$ & 30 \\
\hline 21 & Tubulin-specific chaperone A & & & & & 25 \\
\hline 22 & Unknown & & & & & \\
\hline 23 & Isocitrate dehydrogenase $(\mathrm{NAD}+)$ subunit alpha & Q99NA5 & 39.58 & 6.47 & $8 / 93$ & 31 \\
\hline 24 & Rab GDP dissociation inhibitor beta & P50399 & 50.50 & 5.90 & $16 / 138$ & 46 \\
\hline 25 & Protein phosphatase 2A, subunit B & P58389 & 36.59 & 5.88 & $9 / 56$ & 29 \\
\hline 26 & Proteasome subunit alpha type 3 & P18422 & 28.40 & 5.30 & $7 / 112$ & 27 \\
\hline 27 & UMP-CMP kinase & Q4KM73 & 22.16 & 5.66 & $10 / 114$ & 50 \\
\hline 28 & Peroxiredoxin-6 & $\mathrm{O} 35244$ & 24.80 & 5.64 & $11 / 64$ & 61 \\
\hline
\end{tabular}

Protein names and accession numbers are listed according to the SWISS-PROT database. MW, molecular weight; pI, isoelectric point.
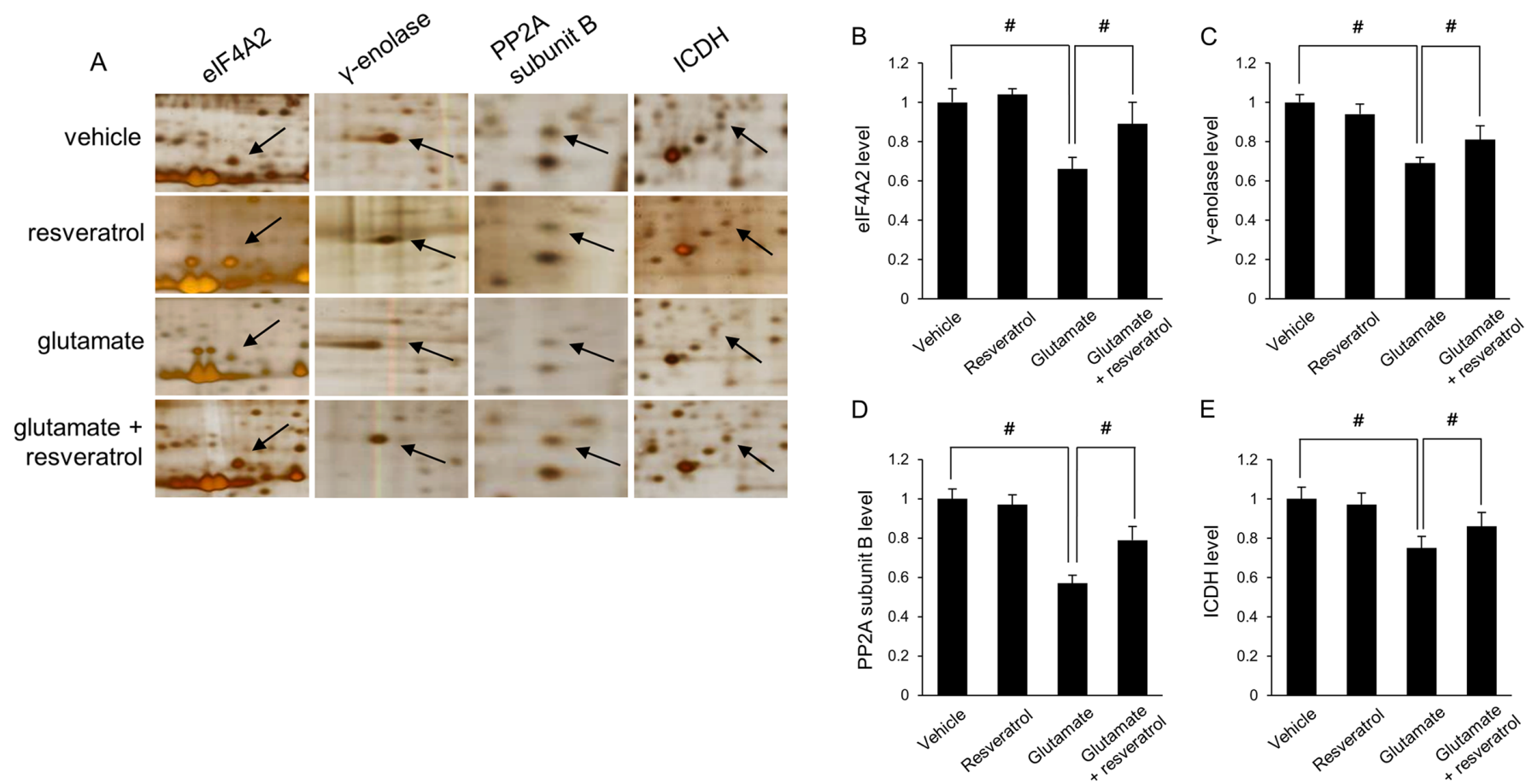

Fig. 3. Image of eukaryotic initiation factor $4 \mathrm{~A} 2$ (eIF4A2), $\gamma$-enolase, protein phosphatase $2 \mathrm{~A}(\mathrm{PP} 2 \mathrm{~A})$ subunit $\mathrm{B}$, and isocitrate dehydrogenase $(\mathrm{ICDH})$ protein spots in neonatal cerebral cortex of vehicle-, resveratrol-, glutamate-, and glutamate and resveratrol co-treated animals. Arrows indicate the identified specific spots. Spot intensities were measured using PDQuest software. Protein levels were determined by the ratio of the intensity of each animals to the vehicle-treated aniamls. Data $(n=4)$ and are shown as the mean \pm S.E.M. ${ }^{\#} P<0.05$. 
metabolism. They were significantly reduced in glutamate-treated animals compared with vehicle-treated animals. These reductions were alleviated by a combination treatment of glutamate and resveratrol. All protein spot intensities are represented as the ratio of protein intensity between drug-treated animals to vehicle-treated animals. The protein spot intensity value for vehicle-treated animals was set to 1 . eIF4A2 levels were $0.66 \pm 0.06$ in glutamate-treated animals and $0.89 \pm 0.11$ in glutamate-resveratrol co-treated animals. $\gamma$-enolase levels were $0.57 \pm 0.04$ and $0.79 \pm 0.07$ in glutamate- and co-treated animals, respectively. Protein phosphatase $2 \mathrm{~A}$ subunit B levels were $0.69 \pm 0.03$ in glutamate-treated animals and $0.81 \pm 0.07$ in co-treated animals. ICDH levels were $0.75 \pm 0.06$ and $0.86 \pm 0.07$ in glutamate- and co-treated animals, respectively.

Western blot analysis confirmed changes of these protein expressions. All protein levels are represented as the ratio of protein intensity to actin intensity (Fig. 4). eIF4A2 levels were $0.28 \pm 0.03$ in glutamate-treated animals and $0.45 \pm 0.04$ in co-treated animals. $\gamma$-enolase levels were $0.31 \pm 0.07$ and $0.71 \pm 0.04$ in glutamate- and co-treated animals, respectively. Protein phosphatase 2A subunit B levels were $0.13 \pm 0.03$ in glutamate-treated animals and $0.39 \pm 0.06$ in co-treated animals. ICDH levels were 0.14 \pm 0.08 and $0.37 \pm 0.03$ in glutamate- and co-treated animals, respectively. Reverse transcription-PCR analysis clearly showed that eIF4A2, $\gamma$-enolase, protein phosphatase $2 \mathrm{~A}$ subunit B, and ICDH levels were reduced in glutamate-treated animals, while resveratrol treatment alleviated these decreases (Fig. 5). eIF4A2 levels were $0.44 \pm 0.07$ and $0.60 \pm 0.06$ in glutamate- and cotreated animals, respectively. $\gamma$-enolase levels were $0.27 \pm 0.07$ in glutamate-treated animals and $0.46 \pm 0.04$ in co-treated animals. Protein phosphatase 2A subunit B levels were $0.36 \pm 0.09$ in glutamate-treated animals and $0.59 \pm 0.04$ in co-treated animals. ICDH expression levels were $0.73 \pm 0.05$ and $0.99 \pm 0.07$ in glutamate- and co-treated animals, respectively. Figure 6 represents a schematic diagram of regulated proteins by resveratrol in neurological damage caused by glutamate in newborns.

\section{DISCUSSION}

Resveratrol is used in a wide range of biological fields because of its beneficial anti-oxidant and anti-inflammatory properties. It has an anti-cancer function by inhibiting the expression of hypoxia-inducing factor and vascular endothelial growth factor [8]. Resveratrol reduces the production of free radical species and increases mitochondrial anti-oxidants [22]. It also has neuroprotective effects against various types of brain damage [11, 54, 63]. We observed severe histopathologic changes caused by glutamate exposed neonatal cerebral cortex. Thus, this study strongly demonstrates that glutamate exposure causes brain cortical damage in newborn rats. Resveratrol alleviated the histopathological changes caused by glutamate exposure. In this study, we used a proteomic approach to identify regulated proteins by resveratrol treatment in cerebral cortices damaged of newborn animals. Among identified proteins, we discussed on specific proteins that associated with oxidative stress, cell-signal transduction, and metabolism.

eIF4A is a translating initiation protein and is an essential factor for binding mRNA and 40S ribosome subunits [34]. It acts as an RNA-dependent ATPase and regulates bidirectional RNA helicase activity in mammalian cells [55]. It is a member of eIF4A DEAD-box protein family and is classified into three isoforms: eIF4A1, eIF4A2, and eIF4A3 [34, 46]. Among the three isoforms, eIF4A2 is expressed extensively in normal tissues and plays an important role in initiating protein synthesis [43]. The protein sequences of eIF4A1 and eIF4A2 are about $90 \%$ similar, and these proteins perform similar functions [46]. In neurons, eIF4A induces ATPase activity and inhibits translation initiation by binding to the brain cytoplasm 1-RNA [32, 62]. Additionally, it interacts with embryonic fatal abnormal vision-like protein 4 to regulate neurodevelopment, and modulates synthesis of Alzheimer's disease-related proteins, including amyloid precursor proteins and tau proteins [3, 9]. Brain cytoplasm 1-RNA is activated by binding to eIF4A and can regulate neuronal excitation inhibition homeostasis through the regulation of metabotropic glutamate receptors [69]. Regulation of neurological excitability is one of the major neurotoxic mechanisms of glutamate [29]. Our results showed that glutamate exposure reduces eIF4A2 expression in the cerebral cortex of newborns. Resveratrol treatment attenuates eIF4A2 down-regulation in brains with cortical damage caused by glutamate exposure. We confirmed these results through Western blot analysis and reverse-transcription PCR techniques. Reduction in eIF4A2 expression inhibits protein synthesis initiation and results in neuronal cell death and neuronal dysfunction [7]. Therefore, our results suggest that maintenance of eIF4A2 expression by resveratrol treatment contributes a neuroprotective function in glutamate-damaged neurons.

Enolases act as glycolytic enzymes that mediate cellular growth and differentiation [52]. They have various subtypes including $\alpha-, \beta-$, and $\gamma$-enolase. $\gamma$-enolase is a neuron-specific enolase because it is abundant in neurons and neuroendocrine cells [40, 53]. It also enhances neuronal differentiation, neurite outgrowth and axon growth, and consequently promotes neuronal tissue growth as a neurotrophic factor $[15,59]$. However, neuron-specific enolase down-regulation induces neurodegeneration $[15,47,59]$. Therefore, $\gamma$-enolase considers a marker of neurodegenerative disorder. We previously showed that $\gamma$-enolase expression was reduced in focal cerebral ischemia caused by middle cerebral artery occlusion [19]. This study showed that glutamate reduces $\gamma$-enolase expression in the neonatal cerebral cortex, while resveratrol attenuates this decrease. $\gamma$-enolase has been reported to promote cell survival and neurite outgrowth by activating the PI3K/Akt signaling pathway [14]. Additionally, resveratrol prevents neuronal cell death during brain damage through activation of the $\mathrm{PI} 3 \mathrm{~K} /$ Akt signaling pathway [1]. Our results demonstrate that glutamate toxicity reduces $\gamma$-enolase expression and promotes neuronal cell death. Resveratrol prevents $\gamma$-enolase reduction by glutamate and reduces neuronal cell death due to glutamate toxicity. Maintenance of $\gamma$-enolase expression has important implications for protecting neurons from damage. Thus, this study demonstrates that resveratrol can protect neurons from glutamate toxicity by regulating $\gamma$-enolase expression in the cerebral cortex of newborn rats.

Protein phosphatase $2 \mathrm{~A}$ is a serine and threonine phosphatase that is ubiquitously found in mammalian cells. It performs various cellular functions such as division, growth, and death [17]. Protein phosphatase 2A is known as an important regulator of extracellular signal-regulating kinase (ERK)/mitogen-activated protein kinase in the extracellular signal transduction pathway. It controls transcription in the endoplasmic reticulum through ERK signaling [37, 49]. Protein phosphatase 2A consists of three subunits: 

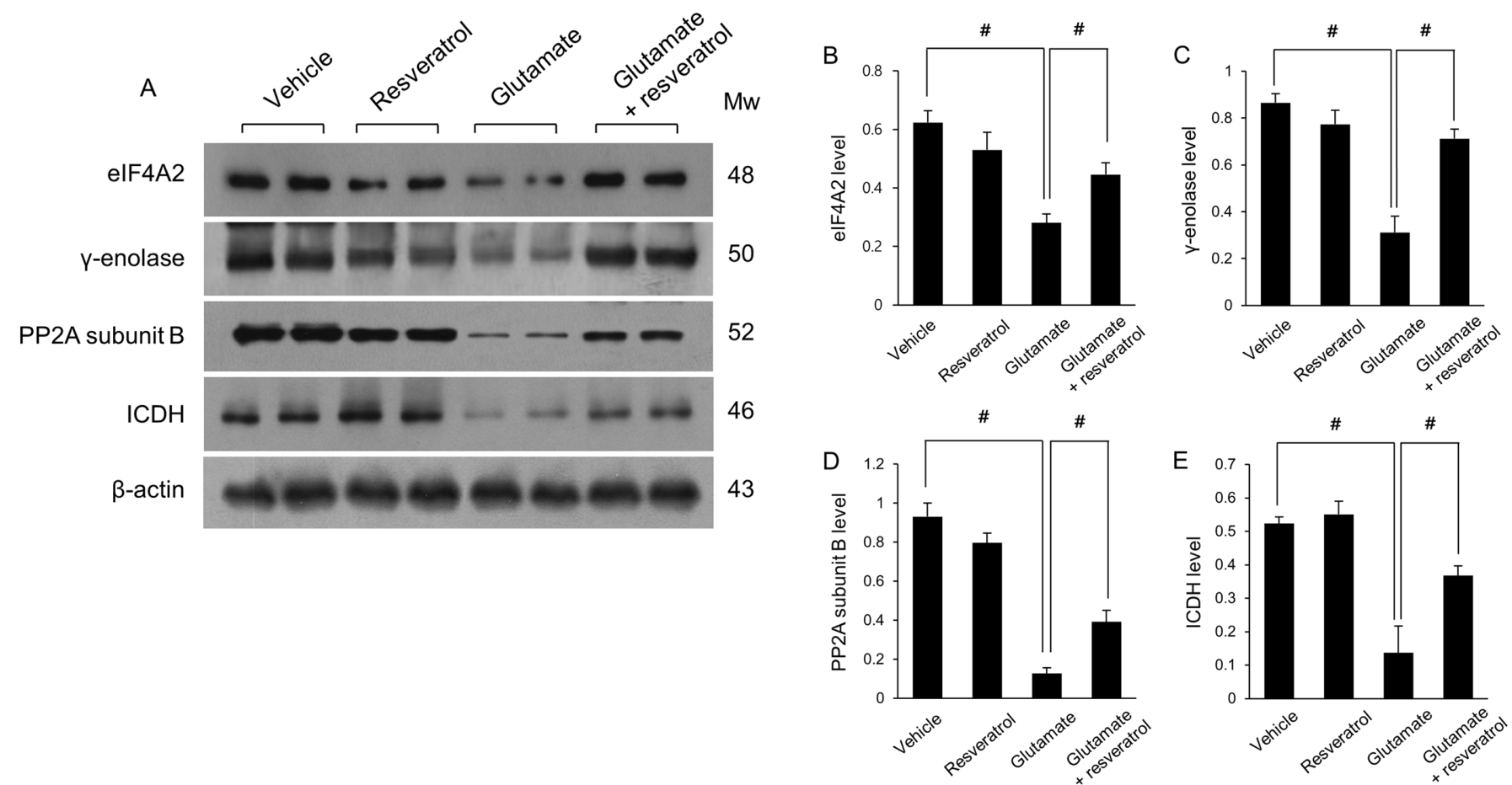

Fig. 4. Western blot analysis of eukaryotic initiation factor 4A2 (eIF4A2), $\gamma$-enolase, protein phosphatase 2A (PP2A) subunit B, and isocitrate dehydrogenase (ICDH) protein spots in neonatal cerebral cortex of vehicle-, resveratrol-, glutamate-, and glutamate and resveratrol co-treated animals. Each lane represents an individual experimental animal. Protein levels were determined by the ratio of the intensity of each protein to $\beta$-actin intensity. Data ( $\mathrm{n}=5$ per group) are presented as mean \pm S.E.M. ${ }^{\#} P<0.05$.
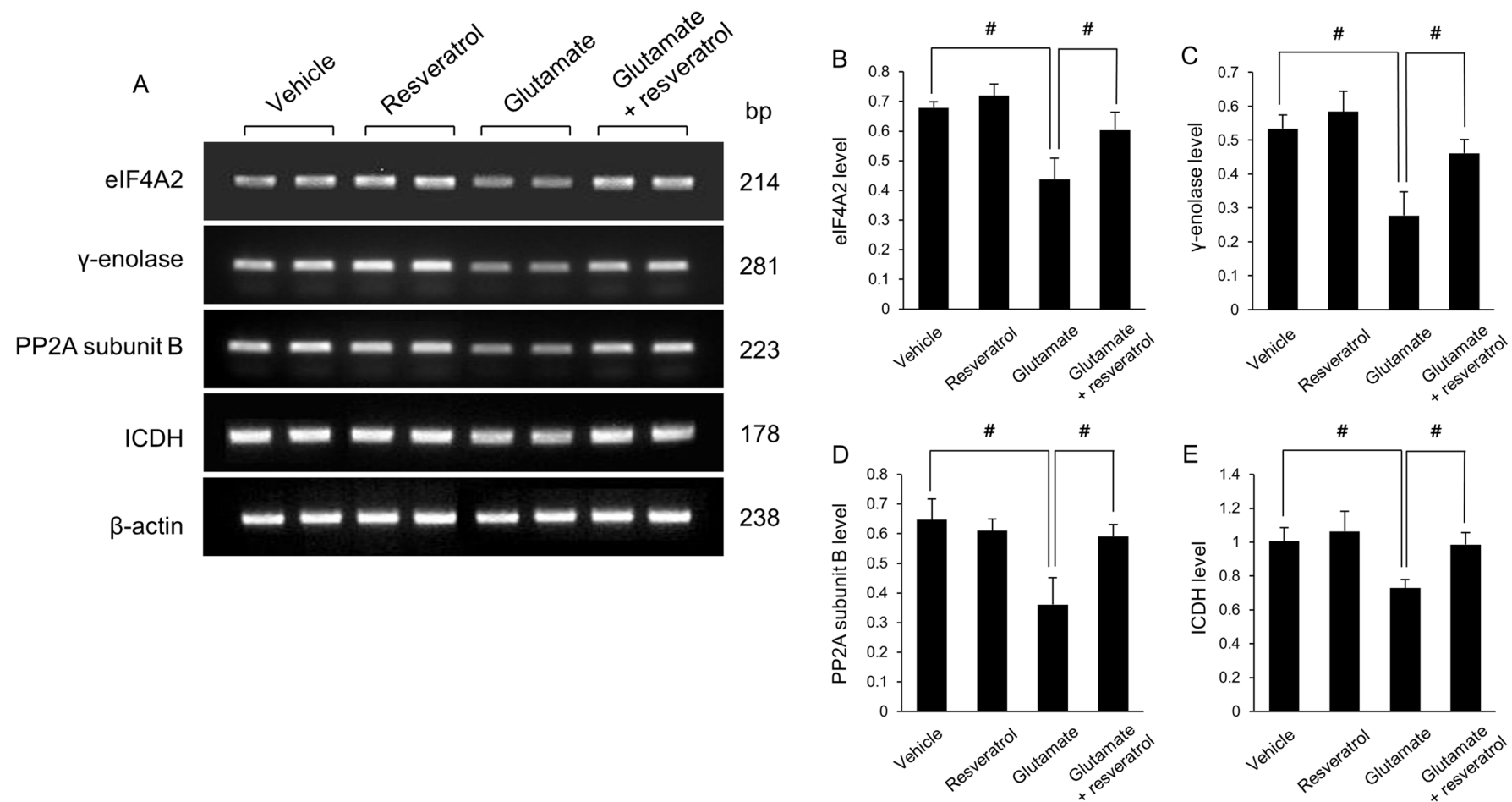

Fig. 5. Reverse transcription-PCR of eukaryotic initiation factor $4 \mathrm{~A} 2$ (eIF4A2), $\gamma$-enolase, protein phosphatase $2 \mathrm{~A}$ (PP2A) subunit $\mathrm{B}$, and isocitrate dehydrogenase $(\mathrm{ICDH})$ protein spots in neonatal cerebral cortex of vehicle-, resveratrol-, glutamate-, and glutamate and resveratrol co-treated animals. Each lane represents an individual experimental animal. The band intensity of reverse transcription-PCR product was normalized to that of $\beta$-actin product. Data ( $\mathrm{n}=5$ per group) are presented as mean \pm S.E.M. ${ }^{\sharp} P<0.05$. 
structural A, regulatory B, and catalytic C. Subunits A and $\mathrm{C}$ are distributed throughout various tissues, and subunit B is mainly found in brain tissue [41]. Subunit B plays an important role in axon growth, synaptic formation, and brain development [58]. We found that glutamate reduces protein phosphatase $2 \mathrm{~A}$ subunit $\mathrm{B}$ expression in the newborn cerebral cortex, while resveratrol attenuates this decrease caused by glutamate. Decrease in protein phosphatase 2A expression is involved in intracellular neurofibrillary tangles formation and leads to neurodegenerative disorders such as Alzheimer's disease [12]. Furthermore, a decrease in protein phosphatase $2 \mathrm{~A}$ activity phosphorylates tau protein and causes axonal degeneration and neurological disorders [35]. We previously reported that decreases of protein phosphatase $2 \mathrm{~A}$ subunit B in focal cerebral ischemia mediates neuronal damage [27]. Taken together, we can demonstrate that protein phosphatase 2 A reduction leads to neurological dysfunction and disability. Our results clearly show that resveratrol alleviated a decrease in protein phosphatase $2 \mathrm{~A}$ subunit $\mathrm{B}$ expression due to glutamate exposure in the neonatal cerebral cortex. Protein phosphatase 2A subunit B expression prevents neuronal cell damage. Thus, we can demonstrate that resveratrol protects neurons from glutamate toxicity through alleviating protein phosphatase 2A subunit B expression decrease in brain damage of newborn rats.

$\mathrm{ICDH}$ is an enzyme that participates in the tricarboxylic acid cycle. It is located in mitochondria and is involved in energy metabolism and mitochondrial function. ICDH catalyzes oxidative decarboxylation to convert isocitrate into $\alpha$-ketoglutarate and produce NADPH from NADP+ [10]. NADPH is the major proton donor in the reactive oxygen species scavenging pathway [20, 30]. Glucose is the only energy source in the central nervous system. Because of the high metabolic rate of neurons, changes in glucose metabolism have a decisive effect on survival $[13,56]$. Glucose metabolism inhibits neuronal apoptosis signaling pathways through regulation of the redox cycle [60]. ICDH is also associated with glutamate metabolism in neurons [28]. It is widely expressed in neurons, astrocytes, oligodendrocytes, and microglial cells in the central nervous system [45]. It is also involved in protective processes against oxidative stress $[2,30]$. ICDH protects macrophages from nitric oxide and reactive oxygen species [38]. Thus, ICDH is an important factor in restoring the energy state in neurons during ischemic brain damage [13]. Our proteomics approach showed that ICDH expression decreased in damaged cerebral cortices by glutamate exposure and resveratrol treatment recovered this decrease. Western blot and reverse transcription-PCR analyses confirmed that resveratrol alleviates the ICDH expression decrease caused by glutamate exposure. Resveratrol regulates mitochondrial peroxidases that reduce oxidative stress and protects neuron by regulating mitochondrial dysfunction during cerebral ischemia [50,66]. Resveratrol also protects cardiac cells from myocardial infarction by increasing adenylate kinase and activating ICDH [33]. A decrease in ICDH expression results in energy metabolism changes, and an increase in ICDH expression alleviates energy metabolism disorder in brain damage [13]. Maintenance of ICDH levels is critical for restoring homeostasis of glucose metabolism in ischemia-damaged neurons [13]. Therefore, our findings suggest that resveratrol exerts a neuroprotective effect by regulating ICDH expression and energy metabolism in neonatal cerebral cortex damage caused by glutamate.

In this study, we elucidated the neuroprotective effect of resveratrol in glutamate-induced brain damage of newborn rats. We also identified that resveratrol regulates the expression of various proteins, such as eIF4A2, $\gamma$-enolase, protein phosphatase $2 \mathrm{~A}$ subunit B, and ICDH. These proteins are associated with anti-oxidants, cellular signaling, and glucose metabolism. Resveratrol prevents reduction in these proteins caused by glutamate induction in newborn animals. Glutamate toxicity causes neurological disorder not only in adults but also in newborns [31, 36]. Clinically, it causes epilepsy in newborns [36]. Taken together, the neuroprotective effect of resveratrol on glutamate toxicity in newborns demonstrates that resveratrol will be effective in neonatal epilepsy. In conclusion, resveratrol has a neuroprotective effect on the newborn cerebral cortex against glutamate toxicity through regulation of various proteins. Our results suggest that resveratrol can be used as a useful substance for treating neurological damage in newborn animals during neurodevelopment.

COMPETING FINANCIAL INTERESTS. The authors declare no competing financial interests

ACKNOWLEDGMENT. This research was supported by the National Research Foundation (NRF) of Korea grant funded by the Korea government (MEST) (NRF-2018R1D1A1B07044074).

\section{REFERENCES}

1. Abdel-Aleem, G. A., Khaleel, E. F., Mostafa, D. G. and Elberier, L. K. 2016. Neuroprotective effect of resveratrol against brain ischemia reperfusion injury in rats entails reduction of DJ-1 protein expression and activation of PI3K/Akt/GSK3b survival pathway. Arch. Physiol. Biochem. 122: 200-213. [Medline] [CrossRef]

2. Benderdour, M., Charron, G., Comte, B., Ayoub, R., Beaudry, D., Foisy, S., Deblois, D. and Des Rosiers, C. 2004. Decreased cardiac mitochondrial NADP+-isocitrate dehydrogenase activity and expression: a marker of oxidative stress in hypertrophy development. Am. J. Physiol. Heart Circ. 
Physiol. 287: H2122-H2131. [Medline] [CrossRef]

3. Bottley, A., Phillips, N. M., Webb, T. E., Willis, A. E. and Spriggs, K. A. 2010. eIF4A inhibition allows translational regulation of mRNAs encoding proteins involved in Alzheimer's disease. PLoS One 5: e13030. [Medline] [CrossRef]

4. Butler, A. K., Uryu, K. and Chesselet, M. F. 1998. A role for N-methyl-D-aspartate receptors in the regulation of synaptogenesis and expression of the polysialylated form of the neural cell adhesion molecule in the developing striatum. Dev. Neurosci. 20: 253-262. [Medline] [CrossRef]

5. Chaparro-Huerta, V., Rivera-Cervantes, M. C., Flores-Soto, M. E., Gómez-Pinedo, U. and Beas-Zárate, C. 2005. Proinflammatory cytokines and apoptosis following glutamate-induced excitotoxicity mediated by p38 MAPK in the hippocampus of neonatal rats. J. Neuroimmunol. 165: 53-62. [Medline] [CrossRef]

6. Choi, D. W. 1988. Glutamate neurotoxicity and diseases of the nervous system. Neuron 1: 623-634. [Medline] [CrossRef]

7. Costa-Mattioli, M., Sonenberg, N. and Richter, J. D. 2009. Translational regulatory mechanisms in synaptic plasticity and memory storage. Prog. Mol. Biol. Transl. Sci. 90: 293-311. [Medline] [CrossRef]

8. Diaz-Gerevini, G. T., Repossi, G., Dain, A., Tarres, M. C., Das, U. N. and Eynard, A. R. 2016. Beneficial action of resveratrol: How and why? Nutrition 32: 174-178. [Medline] [CrossRef]

9. Fukao, A., Sasano, Y., Imataka, H., Inoue, K., Sakamoto, H., Sonenberg, N., Thoma, C. and Fujiwara, T. 2009. The ELAV protein HuD stimulates cap-dependent translation in a Poly(A)- and eIF4A-dependent manner. Mol. Cell 36: 1007-1017. [Medline] [CrossRef]

10. Gálvez, S. and Gadal, P. 1995. On the function of the NADP-dependent isocitrate dehydrogenase isoenzymes in living organisms. Plant Sci. 105: 1-14. [CrossRef]

11. Gao, Z. B., Chen, X. Q. and Hu, G. Y. 2006. Inhibition of excitatory synaptic transmission by trans-resveratrol in rat hippocampus. Brain Res. 1111: 41-47. [Medline] [CrossRef]

12. Gong, C. X., Lidsky, T., Wegiel, J., Zuck, L., Grundke-Iqbal, I. and Iqbal, K. 2000. Phosphorylation of microtubule-associated protein tau is regulated by protein phosphatase $2 \mathrm{~A}$ in mammalian brain. Implications for neurofibrillary degeneration in Alzheimer's disease. J. Biol. Chem. 275: 5535-5544. [Medline] [CrossRef]

13. Grelli, K. N., Palubinsky, A. M., Kale, A. C., Lizama-Manibusan, B. N., Stankowski, J. N., Milne, G. L., Singer, R. and McLaughlin, B. 2013. Alteration of isocitrate dehydrogenase following acute ischemic injury as a means to improve cellular energetic status in neuroadaptation. CNS Neurol. Disord. Drug Targets 12: 849-860. [Medline] [CrossRef]

14. Hafner, A., Obermajer, N. and Kos, J. 2012. $\gamma$-Enolase C-terminal peptide promotes cell survival and neurite outgrowth by activation of the PI3K/ Akt and MAPK/ERK signalling pathways. Biochem. J. 443: 439-450. [Medline] [CrossRef]

15. Hattori, T., Takei, N., Mizuno, Y., Kato, K. and Kohsaka, S. 1995. Neurotrophic and neuroprotective effects of neuron-specific enolase on cultured neurons from embryonic rat brain. Neurosci. Res. 21: 191-198. [Medline] [CrossRef]

16. Jang, J. H. and Surh, Y. J. 2003. Protective effect of resveratrol on beta-amyloid-induced oxidative PC12 cell death. Free Radic. Biol. Med. 34: 1100-1110. [Medline] [CrossRef]

17. Janssens, V. and Goris, J. 2001. Protein phosphatase 2A: a highly regulated family of serine/threonine phosphatases implicated in cell growth and signalling. Biochem. J. 353: 417-439. [Medline] [CrossRef]

18. Jasiński, M., Jasińska, L. and Ogrodowczyk, M. 2013. Resveratrol in prostate diseases-a short review. Cent. European J. Urol. 66: 144-149. [Medline]

19. Jeon, S. J., Kim, M. O., Ali-Shah, F. and Koh, P. O. 2017. Quercetin attenuates the injury-induced reduction of $\gamma$-enolase expression in a middle cerebral artery occlusion animal model. Lab. Anim. Res. 33: 308-314. [Medline] [CrossRef]

20. Jo, S. H., Son, M. K., Koh, H. J., Lee, S. M., Song, I. H., Kim, Y. O., Lee, Y. S., Jeong, K. S., Kim, W. B., Park, J. W., Song, B. J. and Huh, T. L. 2001. Control of mitochondrial redox balance and cellular defense against oxidative damage by mitochondrial NADP+-dependent isocitrate dehydrogenase. J. Biol. Chem. 276: 16168-16176. [Medline] [CrossRef]

21. Johnston, M. V. 2005. Excitotoxicity in perinatal brain injury. Brain Pathol. 15: 234-240. [Medline] [CrossRef]

22. Kairisalo, M., Bonomo, A., Hyrskyluoto, A., Mudò, G., Belluardo, N., Korhonen, L. and Lindholm, D. 2011. Resveratrol reduces oxidative stress and cell death and increases mitochondrial antioxidants and XIAP in PC6.3-cells. Neurosci. Lett. 488: 263-266. [Medline] [CrossRef]

23. Kiss, P., Tamas, A., Lubics, A., Szalai, M., Szalontay, L., Lengvari, I. and Reglodi, D. 2005. Development of neurological reflexes and motor coordination in rats neonatally treated with monosodium glutamate. Neurotox. Res. 8: 235-244. [Medline] [CrossRef]

24. Kiss, P., Hauser, D., Tamás, A., Lubics, A., Rácz, B., Horvath, Z. S., Farkas, J., Zimmermann, F., Stepien, A., Lengvari, I. and Reglódi, D. 2007. Changes in open-field activity and novelty-seeking behavior in periadolescent rats neonatally treated with monosodium glutamate. Neurotox. Res. 12: 85-93. [Medline] [CrossRef]

25. Kiziltepe, U., Turan, N. N., Han, U., Ulus, A. T. and Akar, F. 2004. Resveratrol, a red wine polyphenol, protects spinal cord from ischemiareperfusion injury. J. Vasc. Surg. 40: 138-145. [Medline] [CrossRef]

26. Koh, P. O. 2010. Proteomic analysis of focal cerebral ischemic injury in male rats. J. Vet. Med. Sci. 72: 181-185. [Medline] [CrossRef]

27. Koh, P. O. 2011. Focal cerebral ischemia reduces protein phosphatase $2 \mathrm{~A}$ subunit B expression in brain tissue and HT22 cells. Lab. Anim. Res. 27: 73-76. [Medline] [CrossRef]

28. Kugler, P. and Baier, G. 1992. Mitochondrial enzymes related to glutamate and GABA metabolism in the hippocampus of young and aged rats: a quantitative histochemical study. Neurochem. Res. 17: 179-185. [Medline] [CrossRef]

29. Lau, A. and Tymianski, M. 2010. Glutamate receptors, neurotoxicity and neurodegeneration. Pflugers Arch. 460: 525-542. [Medline] [CrossRef]

30. Lee, S. H., Jo, S. H., Lee, S. M., Koh, H. J., Song, H., Park, J. W., Lee, W. H. and Huh, T. L. 2004. Role of NADP+-dependent isocitrate dehydrogenase (NADP+-ICDH) on cellular defence against oxidative injury by gamma-rays. Int. J. Radiat. Biol. 80: 635-642. [Medline] [CrossRef]

31. Lewerenz, J. and Maher, P. 2015. Chronic glutamate toxicity in neurodegenerative diseases-what is the evidence? Front. Neurosci. 9: 469. [Medline] [CrossRef]

32. Lin, D., Pestova, T. V., Hellen, C. U. and Tiedge, H. 2008. Translational control by a small RNA: dendritic BC1 RNA targets the eukaryotic initiation factor 4A helicase mechanism. Mol. Cell. Biol. 28: 3008-3019. [Medline] [CrossRef]

33. Lin, J. F., Wu, S., Huang, S. S., Lu, B. Y., Lin, S. M. and Tsai, S. K. 2011. Resveratrol protects left ventricle by increasing adenylate kinase and isocitrate dehydrogenase activities in rats with myocardial infarction. Chin. J. Physiol. 54: 406-412. [Medline]

34. Linder, P., Lasko, P. F., Ashburner, M., Leroy, P., Nielsen, P. J., Nishi, K., Schnier, J. and Slonimski, P. P. 1989. Birth of the D-E-A-D box. Nature 337: 121-122. [Medline] [CrossRef]

35. Liu, R. and Wang, J. Z. 2009. Protein phosphatase 2A in Alzheimer's disease. Pathophysiology 16: 273-277. [Medline] [CrossRef]

36. López-Pérez, S. J., Ureña-Guerrero, M. E. and Morales-Villagrán, A. 2010. Monosodium glutamate neonatal treatment as a seizure and excitotoxic model. Brain Res. 1317: 246-256. [Medline] [CrossRef]

37. Lu, Q., Surks, H. K., Ebling, H., Baur, W. E., Brown, D., Pallas, D. C. and Karas, R. H. 2003. Regulation of estrogen receptor alpha-mediated transcription by a direct interaction with protein phosphatase 2A. J. Biol. Chem. 278: 4639-4645. [Medline] [CrossRef] 
38. Maeng, O., Kim, Y. C., Shin, H. J., Lee, J. O., Huh, T. L., Kang, K. I., Kim, Y. S., Paik, S. G. and Lee, H. 2004. Cytosolic NADP(+)-dependent isocitrate dehydrogenase protects macrophages from LPS-induced nitric oxide and reactive oxygen species. Biochem. Biophys. Res. Commun. $\mathbf{3 1 7}$ 558-564. [Medline] [CrossRef]

39. Maher, P. and Davis, J. B. 1996. The role of monoamine metabolism in oxidative glutamate toxicity. J. Neurosci. 16: 6394-6401. [Medline] [CrossRef]

40. Marangos, P. J., Schmechel, D., Parma, A. M., Clark, R. L. and Goodwin, F. K. 1979. Measurement of neuron-specific (NSE) and non-neuronal (NNE) isoenzymes of enolase in rat, monkey and human nervous tissue. J. Neurochem. 33: 319-329. [Medline] [CrossRef]

41. Mayer, R. E., Hendrix, P., Cron, P., Matthies, R., Stone, S. R., Goris, J., Merlevede, W., Hofsteenge, J. and Hemmings, B. A. 1991. Structure of the 55-kDa regulatory subunit of protein phosphatase 2A: evidence for a neuronal-specific isoform. Biochemistry 30: 3589-3597. [Medline] [CrossRef]

42. McEntee, W. J. and Crook, T. H. 1993. Glutamate: its role in learning, memory, and the aging brain. Psychopharmacology (Berl.) 111: $391-401$. [Medline] [CrossRef]

43. Meijer, H. A., Kong, Y. W., Lu, W. T., Wilczynska, A., Spriggs, R. V., Robinson, S. W., Godfrey, J. D., Willis, A. E. and Bushell, M. 2013. Translational repression and eIF4A2 activity are critical for microRNA-mediated gene regulation. Science 340: 82-85. [Medline] [CrossRef]

44. Meldrum, B. S. 2000. Glutamate as a neurotransmitter in the brain: review of physiology and pathology. J. Nutr. 130 Suppl: 1007S-1015S. [Medline] [CrossRef]

45. Minich, T., Yokota, S. and Dringen, R. 2003. Cytosolic and mitochondrial isoforms of NADP+-dependent isocitrate dehydrogenases are expressed in cultured rat neurons, astrocytes, oligodendrocytes and microglial cells. J. Neurochem. 86: 605-614. [Medline] [CrossRef]

46. Nielsen, P. J. and Trachsel, H. 1988. The mouse protein synthesis initiation factor 4 A gene family includes two related functional genes which are differentially expressed. EMBO J. 7: 2097-2105. [Medline] [CrossRef]

47. Parnetti, L., Palumbo, B., Cardinali, L., Loreti, F., Chionne, F., Cecchetti, R. and Senin, U. 1995. Cerebrospinal fluid neuron-specific enolase in Alzheimer's disease and vascular dementia. Neurosci. Lett. 183: 43-45. [Medline] [CrossRef]

48. Park, C. H., Choi, S. H., Piao, Y., Kim, S., Lee, Y. J., Kim, H. S., Jeong, S. J., Rah, J. C., Seo, J. H., Lee, J. H., Chang, K., Jung, Y. J. and Suh, Y. H. 2000. Glutamate and aspartate impair memory retention and damage hypothalamic neurons in adult mice. Toxicol. Lett. 115: 117-125. [Medline] [CrossRef]

49. Pullar, C. E., Chen, J. and Isseroff, R. R. 2003. PP2A activation by beta2-adrenergic receptor agonists: novel regulatory mechanism of keratinocyte migration. J. Biol. Chem. 278: 22555-22562. [Medline] [CrossRef]

50. Robb, E. L., Winkelmolen, L., Visanji, N., Brotchie, J. and Stuart, J. A. 2008. Dietary resveratrol administration increases MnSOD expression and activity in mouse brain. Biochem. Biophys. Res. Commun. 372: 254-259. [Medline] [CrossRef]

51. Rössler, O. G., Bauer, I., Chung, H. Y. and Thiel, G. 2004. Glutamate-induced cell death of immortalized murine hippocampal neurons: neuroprotective activity of heme oxygenase-1, heat shock protein 70, and sodium selenite. Neurosci. Lett. 362: 253-257. [Medline] [CrossRef]

52. Schmechel, D. E., Brightman, M. W. and Marangos, P. J. 1980. Neurons switch from non-neuronal enolase to neuron-specific enolase during differentiation. Brain Res. 190: 195-214. [Medline] [CrossRef]

53. Schmechel, D., Marangos, P. J., Zis, A. P., Brightman, M. and Goodwin, F. K. 1978. Brain endolases as specific markers of neuronal and glial cells. Science 199: 313-315. [Medline] [CrossRef]

54. Shah, F. A., Gim, S. A., Kim, M. O. and Koh, P. O. 2014. Proteomic identification of proteins differentially expressed in response to resveratrol treatment in middle cerebral artery occlusion stroke model. J. Vet. Med. Sci. 76: 1367-1374. [Medline] [CrossRef]

55. Shaoyan, X., Juanjuan, Y., Yalan, T., Ping, H., Jianzhong, L. and Qinian, W. 2013. Downregulation of EIF4A2 in non-small-cell lung cancer associates with poor prognosis. Clin. Lung Cancer 14: 658-665. [Medline] [CrossRef]

56. Silver, I. A. and Erecińska, M. 1998. Glucose-induced intracellular ion changes in sugar-sensitive hypothalamic neurons. J. Neurophysiol. 79: 1733-1745. [Medline] [CrossRef]

57. Sönmez, U., Sönmez, A., Erbil, G., Tekmen, I. and Baykara, B. 2007. Neuroprotective effects of resveratrol against traumatic brain injury in immature rats. Neurosci. Lett. 420: 133-137. [Medline] [CrossRef]

58. Strack, S., Zaucha, J. A., Ebner, F. F., Colbran, R. J. and Wadzinski, B. E. 1998. Brain protein phosphatase 2A: developmental regulation and distinct cellular and subcellular localization by B subunits. J. Comp. Neurol. 392: 515-527. [Medline] [CrossRef]

59. Takei, N., Kondo, J., Nagaike, K., Ohsawa, K., Kato, K. and Kohsaka, S. 1991. Neuronal survival factor from bovine brain is identical to neuronspecific enolase. J. Neurochem. 57: 1178-1184. [Medline] [CrossRef]

60. Vaughn, A. E. and Deshmukh, M. 2008. Glucose metabolism inhibits apoptosis in neurons and cancer cells by redox inactivation of cytochrome c. Nat. Cell Biol. 10: 1477-1483. [Medline] [CrossRef]

61. Virgili, M. and Contestabile, A. 2000. Partial neuroprotection of in vivo excitotoxic brain damage by chronic administration of the red wine antioxidant agent, trans-resveratrol in rats. Neurosci. Lett. 281: 123-126. [Medline] [CrossRef]

62. Wang, H., Iacoangeli, A., Popp, S., Muslimov, I. A., Imataka, H., Sonenberg, N., Lomakin, I. B. and Tiedge, H. 2002. Dendritic BC1 RNA: functional role in regulation of translation initiation. J. Neurosci. 22: 10232-10241. [Medline] [CrossRef]

63. Wang, Q., Yu, S., Simonyi, A., Rottinghaus, G., Sun, G. Y. and Sun, A. Y. 2004. Resveratrol protects against neurotoxicity induced by kainic acid. Neurochem. Res. 29: 2105-2112. [Medline] [CrossRef]

64. West, T., Atzeva, M. and Holtzman, D. M. 2007. Pomegranate polyphenols and resveratrol protect the neonatal brain against hypoxic-ischemic injury. Dev. Neurosci. 29: 363-372. [Medline] [CrossRef]

65. Yang, X., Li, X. and Ren, J. 2014. From French Paradox to cancer treatment: anti-cancer activities and mechanisms of resveratrol. Anticancer. Agents Med. Chem. 14: 806-825. [Medline] [CrossRef]

66. Yousuf, S., Atif, F., Ahmad, M., Hoda, N., Ishrat, T., Khan, B. and Islam, F. 2009. Resveratrol exerts its neuroprotective effect by modulating mitochondrial dysfunctions and associated cell death during cerebral ischemia. Brain Res. 1250: 242-253. [Medline] [CrossRef]

67. Zamin, L. L., Dillenburg-Pilla, P., Argenta-Comiran, R., Horn, A. P., Simão, F., Nassif, M., Gerhardt, D., Frozza, R. L. and Salbego, C. 2006. Protective effect of resveratrol against oxygen-glucose deprivation in organotypic hippocampal slice cultures: Involvement of PI3-K pathway. Neurobiol. Dis. 24: 170-182. [Medline] [CrossRef]

68. Zhang, L. N., Hao, L., Wang, H. Y., Su, H. N., Sun, Y. J., Yang, X. Y., Che, B., Xue, J. and Gao, Z. B. 2015. Neuroprotective effect of resveratrol against glutamate-induced excitotoxicity. Adv. Clin. Exp. Med. 24: 161-165. [Medline] [CrossRef]

69. Zhong, J., Chuang, S. C., Bianchi, R., Zhao, W., Lee, H., Fenton, A. A., Wong, R. K. and Tiedge, H. 2009. BC1 regulation of metabotropic glutamate receptor-mediated neuronal excitability. J. Neurosci. 29: 9977-9986. [Medline] [CrossRef] 